OPEN ACCESS

Edited by:

Nicole McPherson,

University of Adelaide, Australia

Reviewed by:

Iwona Krela-Kaźmierczak,

Poznan University of Medical

Sciences, Poland

Shaun Roman,

University of Newcastle, Australia

*Correspondence:

Angela J. Crean

angela.crean@sydney.edu.au

Specialty section:

This article was submitted to

Reproduction,

a section of the journal

Frontiers in Endocrinology

Received: 28 October 2020

Accepted: 01 February 2021

Published: 11 March 2021

Citation:

Pini T, Raubenheimer D, Simpson SJ and Crean AJ (2021) Obesity and Male

Reproduction; Placing the Western

Diet in Context.

Front. Endocrinol. 12:622292.

doi: 10.3389/fendo.2021.622292

\section{Obesity and Male Reproduction; Placing the Western Diet in Context}

\author{
Taylor Pini, David Raubenheimer, Stephen J. Simpson and Angela J. Crean* \\ Charles Perkins Centre, School of Life and Environmental Sciences, The University of Sydney, Sydney, NSW, Australia
}

There is mounting evidence that obesity has negative repercussions for reproductive physiology in males. Much of this evidence has accumulated from rodent studies employing diets high in fat and sugar ("high fat" or "western" diets). While excessive fats and carbohydrates have long been considered major determinants of diet induced obesity, a growing body of research suggests that the relationships between diet composition and obesity are more complex than originally thought, involving interactions between dietary macronutrients. However, rodent dietary models have yet to evolve to capture this, instead relying heavily on elevated levels of a single macronutrient. While this approach has highlighted important effects of obesity on male reproduction, it does not allow for interpretation of the complex, interacting effects of dietary protein, carbohydrate and fat. Further, the single nutrient approach limits the ability to draw conclusions about which diets best support reproductive function. Nutritional Geometry offers an alternative approach, assessing outcomes of interest over an extended range of dietary macronutrient compositions. This review explores the practical application of Nutritional Geometry to study the effects of dietary macronutrient balance on male reproduction, including experimental considerations specific to studies of diet and reproductive physiology. Finally, this review discusses the promising use of Nutritional Geometry in the development of evidence-based preconception nutritional guidance for men.

Keywords: obesity, male fertility, reproduction, diet, high fat, nutritional geometry

\section{INTRODUCTION}

Obesity affects millions of people globally. Men of reproductive age (18-64 years) are no exception, with averages of $37.8 \%$ (1), $31.4 \%$ (2), and $29.9 \%$ (3) classified as obese (body mass index $\geq 30 \mathrm{~kg} /$ $\mathrm{m}^{2}$ ) in the United States, Australia, and the United Kingdom, respectively. Because of its epidemiological prevalence, the impacts of obesity have been studied in the context of many biological processes, including reproduction. While much of the literature has focused on female reproduction, a growing body of evidence suggests that obesity and associated metabolic dysfunction can alter spermatozoa on a molecular level $(4,5)$, negatively affect sperm function (6-8), alter circulating levels of reproductive hormones (9), cause male sub-fertility $(10,11)$ and impart epigenetic changes to spermatozoa which ultimately decrease offspring metabolic health (12) and reproductive potential (13). In addition, a wide range of intrinsic [e.g., DAZ deletion (14), age (15)] and extrinsic [e.g., radiation exposure (16), tobacco use (17)] factors can contribute to male 
infertility, and may interact with or compound the effects of obesity on male reproduction (Figure 1). While male obesity is generally recognized as an important concern in the context of reproductive medicine (18-20), some studies question the effects of obesity on semen parameters and male fertility (21-25). These inconsistencies and the seriousness of the potential consequences of obesity on male fertility necessitate continued research efforts in this field.

The root cause of obesity is a topic which has been debated for decades. While there is a growing number of risk factors associated with obesity, including sleep, genetic background, and physical activity, diet is the most significant contributor (26). Many have identified lipid as the major dietary determinant $(27,28)$, but this has been refuted by others who consider carbohydrate to be the major culprit (29-31). In contrast to these single-nutrient explanations, there is mounting evidence that obesity may instead be driven by an altered macronutrient balance in the diet, rather than by high dietary fat or carbohydrate alone (32-34). Despite this, animal studies employing purified diets with elevated concentrations of fat (typically referred to as "high fat" or "western" diets) remain a staple of research investigating diet induced obesity (35). As the understanding of what constitutes an obesogenic diet changes, there is a need to rethink the dietary models which are used to study obesity and its downstream consequences for such factors as reproduction.

In this review, we summarise the limitations of the traditional western diet approach and introduce Nutritional Geometry as a powerful framework for studying the relationships between diet, obesity, and male reproduction. We also highlight important experimental design considerations unique to studying male reproductive physiology. Finally, we pose potential applications for Nutritional Geometry in the context of male reproduction, including a path toward the development of pre-conception nutritional guidelines.

\section{THE CURRENT APPROACH TO STUDYING OBESITY AND MALE REPRODUCTION}

Evidence from animal studies indicates that obesity and associated metabolic disease are deleterious for male reproduction (Table 1). A variety of processes are reportedly impacted by obesity, including testosterone production (7), testicular gene expression (36-38), production of reactive oxygen species $(6,8)$, and maintenance of the blood-testis barrier (7). These studies compare the effects of diets which contain normal $(10 \%-18 \%$ of total kcal) or high $(40 \%-60 \%$ of total $\mathrm{kcal}$ ) amounts of fat, with some also incorporating elevated levels of sucrose. Rodent diets high in the proportion of fat are excellent tools to create an obese phenotype, resulting in significantly larger adipose tissue depots (6) and a higher overall percentage body fat compared to lean mass $(37,42)$. These high-fat diets also often capture metabolic sequelae, including elevated serum cholesterol, triglycerides, glucose, insulin, and leptin $(6,37,42)$, though this is not always the

\section{Risk factors for male infertility}
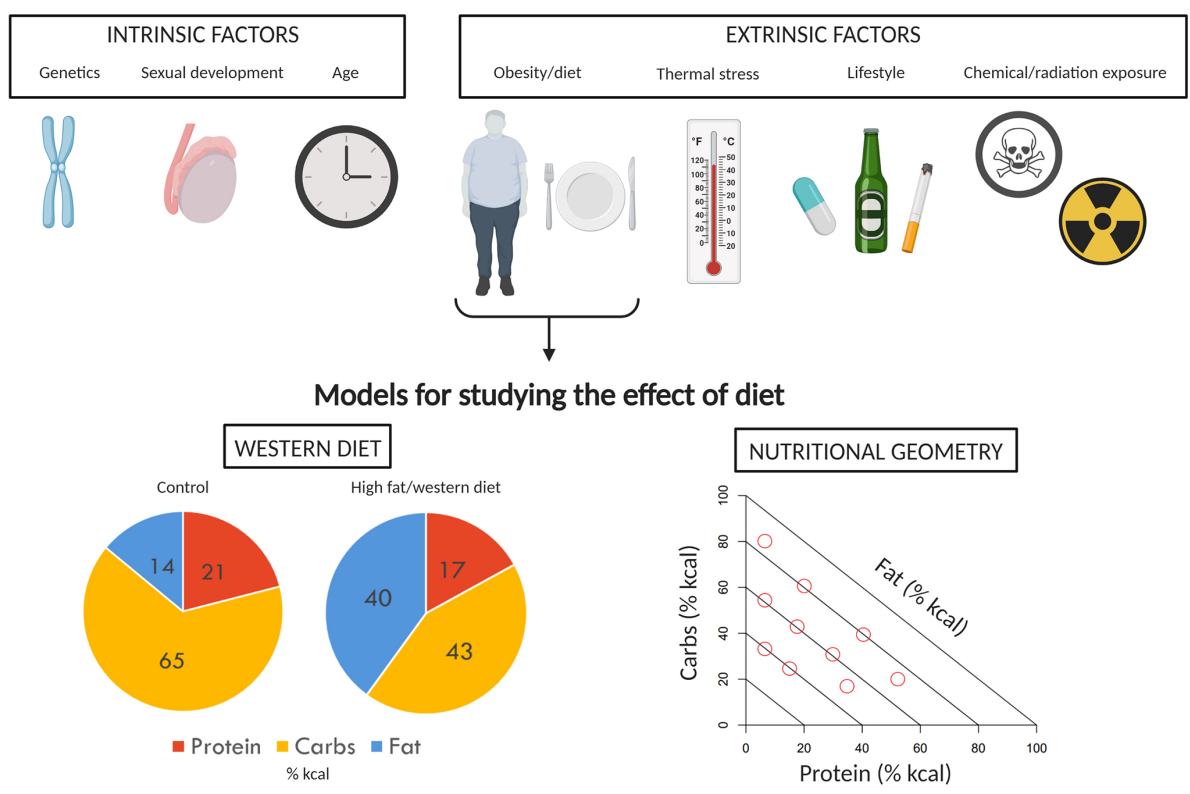

FIGURE 1 | Factors impacting male fertility and models to study effects of diet. A variety of intrinsic and extrinsic factors can contribute to poor reproductive performance and infertility in men. Of the extrinsic factors, the impact of diet and obesity on male reproduction has received a significant amount of attention. The effects of diet and obesity on male reproduction are typically investigated in rodents using the classic "western diet" approach, comparing control and treatment diet outcomes. Here, we instead propose the use of Nutritional Geometry, employing a range of diets which systematically differ in their proportions of protein, carbohydrates, and fat. Image created with BioRender.com. 
TABLE 1 | Rodent studies employing a traditional high fat/western diet approach to study the impact of obesity on male reproduction.

\begin{tabular}{|c|c|c|c|c|c|c|c|c|c|c|c|c|c|c|c|c|}
\hline \multirow[t]{2}{*}{ Reference } & \multirow[t]{2}{*}{ Diet } & \multirow[t]{2}{*}{ Diet type } & \multirow[t]{2}{*}{ Species } & \multirow{2}{*}{$\begin{array}{l}\text { Age at } \\
\text { start }\end{array}$} & \multirow{2}{*}{$\begin{array}{c}\text { Treatment } \\
\text { length }\end{array}$} & \multirow{2}{*}{$\begin{array}{c}\mathrm{kcal} / \\
\mathrm{g}\end{array}$} & \multirow{2}{*}{$\begin{array}{c}\% \\
\text { protein }\end{array}$} & \multirow{2}{*}{$\begin{array}{c}\% \\
\text { carb }\end{array}$} & \multirow{2}{*}{$\begin{array}{l}\% \\
\text { fat }\end{array}$} & \multirow[t]{2}{*}{ P:C } & \multirow[t]{2}{*}{ P:F } & \multirow{2}{*}{$\begin{array}{c}\text { Unique } \\
\text { ingredients }\end{array}$} & \multicolumn{4}{|c|}{ Outcomes } \\
\hline & & & & & & & & & & & & & Testis & $\begin{array}{l}\text { Epididymis/ } \\
\text { Accessory sex } \\
\text { glands }\end{array}$ & Sperm & $\begin{array}{l}\text { Mating/ } \\
\text { offspring }\end{array}$ \\
\hline \multirow[t]{2}{*}{ (7) } & \multirow{2}{*}{$\begin{array}{l}\text { MD12031 10\% fat, } \\
\text { Mediscience Ltd } \\
\text { MD12032 45\% fat, } \\
\text { Mediscience Ltd }\end{array}$} & Grain-based & \multirow[t]{2}{*}{$\begin{array}{l}\text { Mouse } \\
\text { (C57BL/6) }\end{array}$} & \multirow[t]{2}{*}{$5 \mathrm{wk}$} & \multirow[t]{2}{*}{$10 \mathrm{wk}$} & \multirow[t]{2}{*}{ - } & 20 & 70 & 10 & 3.5 & 0.5 & & \multirow{2}{*}{$\begin{array}{l}\text { Disrupted blood-testis } \\
\text { barrier, decreased } \\
\text { testosterone }\end{array}$} & & \multirow{2}{*}{$\begin{array}{l}\text { Decreased sperm } \\
\text { motility, normal } \\
\text { morphology }\end{array}$} & \\
\hline & & $\begin{array}{l}\text { Grain-based + } \\
\text { purified }\end{array}$ & & & & & 20 & 35 & 45 & 1.8 & 2.3 & $\begin{array}{l}\text { Sucrose, } \\
\text { lard, } \\
\text { cholesterol }\end{array}$ & & & & \\
\hline \multirow[t]{2}{*}{ (36) } & \multirow{2}{*}{$\begin{array}{l}\text { 824050, } \\
\text { Special Diet Services } \\
\text { UK } \\
824053, \\
\text { Special Diet Services } \\
\text { UK }\end{array}$} & Purified & \multirow[t]{2}{*}{$\begin{array}{l}\text { Mouse } \\
\text { (C57BL/6) }\end{array}$} & \multirow[t]{2}{*}{$3 \mathrm{wk}$} & \multirow[t]{2}{*}{$8 \mathrm{wk}$} & 4.5 & 20 & 70 & 10 & 3.5 & 0.5 & & \multirow[t]{2}{*}{$\begin{array}{l}\text { Increased Cyp2e1, } \\
\text { Cyp19a1, Pparg and } \\
\text { Tnf mRNA in testis }\end{array}$} & & \multirow[t]{2}{*}{$\begin{array}{l}\text { Increased sperm DNA } \\
\text { fragmentation }\end{array}$} & \\
\hline & & Purified & & & & 3.7 & 20 & 35 & 45 & 1.8 & 2.3 & Lard & & & & \\
\hline \multirow[t]{2}{*}{ (37) } & $\begin{array}{l}\text { D12450Bi, Research } \\
\text { Diets Inc }\end{array}$ & Purified & $\begin{array}{l}\text { Mouse } \\
\text { (C57BL/6J) }\end{array}$ & $5 \mathrm{wk}$ & $25 \mathrm{wk}$ & 3.8 & 20 & 70 & 10 & 3.5 & 0.5 & Corn starch & $\begin{array}{l}\text { Increased Pparg } \\
\text { mRNA, decresed }\end{array}$ & & $\begin{array}{l}\text { Decreased sperm } \\
\text { motility }\end{array}$ & $\begin{array}{l}\text { Decreased } \\
\text { pregnancy rates }\end{array}$ \\
\hline & $\begin{array}{l}\text { D12492i, } \\
\text { Research Diets Inc }\end{array}$ & Purified & & & & 5.2 & 20 & 20 & 60 & 1.0 & 3.0 & & $\begin{array}{l}\text { Crem, Dhh, lgft, Lepr, } \\
\text { Sh2b1 mRNA in testis }\end{array}$ & & & \\
\hline (38) & $\begin{array}{l}\text { SF04-057, } \\
\text { Specialty Feeds }\end{array}$ & Purified & $\begin{array}{l}\text { Mouse } \\
\text { (C57BL/6) }\end{array}$ & $5 \mathrm{wk}$ & $10 \mathrm{wk}$ & 3.8 & 21 & 65 & 14 & 3.1 & 0.7 & & $\begin{array}{l}\text { Altered testis } \\
\text { transcriptome, }\end{array}$ & & $\begin{array}{l}\text { Altered sperm } \\
\text { miRNAs }\end{array}$ & \\
\hline & $\begin{array}{l}\text { SF00-219, } \\
\text { Specialty Feeds }\end{array}$ & Purfied & & & & 4.6 & 17 & 43 & 40 & 2.5 & 2.4 & Ghee & $\begin{array}{l}\text { decreased global } \\
\text { methylation of testis } \\
\text { and spermatid DNA }\end{array}$ & & & \\
\hline (6) & $\begin{array}{l}\text { SF04-057, } \\
\text { Soecialty Feeds }\end{array}$ & Purified & $\begin{array}{l}\text { Mouse } \\
\text { (C57BL/6) }\end{array}$ & $6 \mathrm{wk}$ & $9 \mathrm{wk}$ & 3.8 & 21 & 65 & 14 & 3.1 & 0.7 & & & & $\begin{array}{l}\text { Decreased sperm } \\
\text { motility zona binding }\end{array}$ & \\
\hline & $\begin{array}{l}\text { SF00-219, } \\
\text { Specialty Feeds }\end{array}$ & Purified & & & & 4.6 & 17 & 43 & 40 & 2.5 & 2.4 & Ghee & & & $\begin{array}{l}\text { increased ROS, DNA } \\
\text { fragmentation }\end{array}$ & \\
\hline (39) & $\begin{array}{l}\text { SF04-057, } \\
\text { Specialty Feeds }\end{array}$ & Purified & $\begin{array}{l}\text { Mouse } \\
\text { (C57BL/6) }\end{array}$ & $5 \mathrm{wk}$ & $18 \mathrm{wk}$ & 3.8 & 21 & 65 & 14 & 3.1 & 0.7 & & & & & $\begin{array}{l}\text { Decreased total } \\
\text { embryo cell }\end{array}$ \\
\hline & $\begin{array}{l}\text { SF00-219, } \\
\text { Specialty Feeds }\end{array}$ & Purified & & & & 4.6 & 17 & 43 & 40 & 2.5 & 2.4 & Ghee & & & & $\begin{array}{l}\text { number (TE and } \\
\text { ICM), } \\
\text { implantations, } \\
\text { fetal weight, } \\
\text { crown-rump } \\
\text { length, placental } \\
\text { weight }\end{array}$ \\
\hline (13) & $\begin{array}{l}\text { SF04-057, } \\
\text { Specialty Feeds }\end{array}$ & Purified & $\begin{array}{l}\text { Mouse } \\
\text { (C57BL/6 }\end{array}$ & $5 \mathrm{wk}$ & $10 \mathrm{wk}$ & 3.8 & 21 & 65 & 14 & 3.1 & 0.7 & & & & $\begin{array}{l}\text { Altered sperm } \\
\text { miRNAs }\end{array}$ & \\
\hline & $\begin{array}{l}\text { SF00-219, } \\
\text { Specialty Feeds }\end{array}$ & Purified & NHsd) & & & 4.6 & 17 & 43 & 40 & 2.5 & 2.4 & Ghee & & & & \\
\hline (4) & $\begin{array}{l}2016 \text { Global, Envigo } \\
\text { TD. } 88137 \text {, } \\
\text { Envigo }\end{array}$ & $\begin{array}{l}\text { Grain-based } \\
\text { Purified }\end{array}$ & $\begin{array}{l}\text { Mouse } \\
\text { (C57BL/6) }\end{array}$ & $10 \mathrm{wk}$ & $15 \mathrm{wk}$ & $\begin{array}{l}3.0 \\
4.5\end{array}$ & $\begin{array}{c}22 \\
15.2\end{array}$ & $\begin{array}{c}66 \\
42.7\end{array}$ & $\begin{array}{l}12 \\
42\end{array}$ & $\begin{array}{l}3.0 \\
2.8\end{array}$ & $\begin{array}{l}0.5 \\
2.8\end{array}$ & $\begin{array}{l}\text { Milk fat, } \\
\text { sucrose }\end{array}$ & $\begin{array}{l}\text { Decreased Crisp } 4 \text { and } \\
\text { Lepr mRNA in testis }\end{array}$ & $\begin{array}{l}\text { Decreased Crisp4 } \\
\text { mRNA in } \\
\text { epididymis }\end{array}$ & & $\begin{array}{l}\text { Decreased } \\
\text { fertilization, } \\
\text { pregnancy rates }\end{array}$ \\
\hline (40) & $\begin{array}{l}\text { Meat free rat and } \\
\text { mouse chow, } \\
\text { Specialty Feeds }\end{array}$ & Grain-based & $\begin{array}{l}\text { Mouse } \\
\text { (C57BL/6) }\end{array}$ & $6 \mathrm{wk}$ & $10 \mathrm{wk}$ & 3.3 & 23 & 65 & 12 & 2.8 & 0.5 & & & $\begin{array}{l}\text { Increased leptin, } \\
\text { insulin, decreased } \\
\text { estradiol in }\end{array}$ & $\begin{array}{l}\text { Increased sperm } \\
\text { Cox4il mRNA }\end{array}$ & \\
\hline & $\begin{array}{l}\text { SF00-219, } \\
\text { Specialty Feeds }\end{array}$ & Purified & & & & 4.6 & 17 & 43 & 40 & 2.5 & 2.4 & $\begin{array}{l}\text { Ghee, } \\
\text { sucrose }\end{array}$ & & $\begin{array}{l}\text { seminal vesicle } \\
\text { fluid, altered } \\
\text { seminal vesicle } \\
\text { fluid metabolite } \\
\text { composition }\end{array}$ & & \\
\hline (8) & 2018S Global, & Grain-based & Rat & "Sexually & 4 wk & 3.1 & 24 & 58 & 18 & 2.4 & 0.8 & & & & Decreased sperm & \\
\hline & $\begin{array}{l}\text { TD.03584, } \\
\text { Teklad }\end{array}$ & Purfifed & Dawley) & & & 5.4 & 15 & 27 & 58 & 1.8 & 3.9 & Lard & & & $\begin{array}{l}\text { and pyruvate } \\
\text { dehydrogenases, } \\
\text { citrate synthase, } \\
\text { respiratory chain } \\
\text { complexes, } \\
\text { decreased ATP, } \\
\text { increased ROS }\end{array}$ & \\
\hline
\end{tabular}




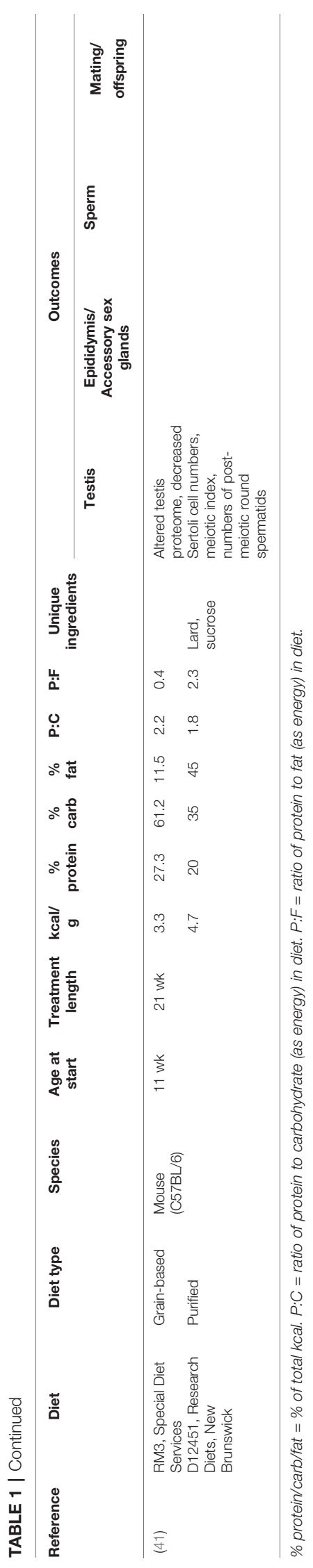

case (43-45). While it would be easy to conclude from these studies that avoiding a high-fat diet will safeguard reproductive potential, the reality is more complicated.

Nutritional studies have shown that it is not just the amount of energy consumed that matters, but from where this energy is sourced. Most dietary energy comes from the three principal classes of macronutrients-protein, carbohydrate, and fat. Carbohydrates are the main source of metabolic fuel, protein provides amino acids for growth, repair and a minimal contribution of metabolic energy, and fats provide a concentrated source of energy. This is reflected in the energy density of each macronutrient-whereas protein and carbohydrates have around $4 \mathrm{kcal} / \mathrm{g}$, fats contain around 9 $\mathrm{kcal} / \mathrm{g}$. This at least partially explains why a high fat diet often leads to increased adiposity, because high fat diets generally contain more calories per gram of food (Table 1). Consequently, it is not clear whether the effects of western diets on male reproduction result from differences in fat or differences in calories. It is thus unclear whether men trying to conceive should be advised to simply eat less or to specifically avoid fats. This distinction is important, as dietary fats are also used in androgen production (46), and therefore the message to avoid fats may actually have negative consequences for male fertility.

Although this review mainly focuses on the impact of overnutrition on male fertility, studies of undernutrition provide a different lens to examine the overall impact of nutrition on reproduction. Two approaches are commonly used; caloric restriction and low protein diets, respectively reflecting decreased food availability and a common dietary deficiency observed in undernourished children (47). With the focus shifted from fat to protein in these models, a host of interesting findings have come to light, leading to a growing recognition of the importance of dietary protein in health and disease. In the context of male reproduction, dietary protein has been demonstrated to impact weights of reproductive organs, reproductive hormone concentrations (48), testicular architecture and occurrence of apoptosis during spermatogenesis (49), testicular expression of DNA methyltransferases, and sperm DNA methylation (50). Further, the level of protein in a father's diet has also been shown to alter subsequent pre-implantation embryo gene expression, placental gene expression and imprinting, fetal bone growth (51), fetal and placental weights, placental structure (52), and adult offspring vascular function (53) and metabolism (50). These results highlight why it is important to consider the effects of dietary protein in addition to fats and carbohydrates when investigating the impact of dietary-induced obesity on reproductive outcomes. This is particularly important because in order to increase the percentage contribution of dietary energy of fat in the standard control versus western diet experimental design, the percentage of protein and/or carbohydrates must be decreased.

This problem of failing to consider macronutrient effects in concert is apparent from a comparison of the typical diets used in animal studies of obesity and reproduction. In addition to differences in the proportion of fat that is used to represent a "high fat" diet, the relative proportional reduction in proteins 
and carbohydrates also varies widely across studies (Table 1). Hence, while results are interpreted in the context of the change in fat content, studies are actually comparing diets which differ across their percentages of protein, carbohydrate, and fat (e.g., see Table 1, diet SF04-057 compared to diet SF00-219, Figure 1). In some cases, studies fix protein and vary only in carbohydrate and fat $(7,36,37)$. In this case, control diets (fat $10 \%$ of total kcal) are high in carbohydrate (70\% of total kcal) and high-fat diets (fat $45 \%-60 \%$ of total kcal) are low in carbohydrate $(20 \%-35 \%$ of total kcal). This type of experimental design gives very little opportunity to disentangle the effects of different macronutrients, as it is not possible to conclude whether results are due to high fat alone, or the combination of higher fat and lower carbohydrate and/or protein. In order to better understand the impacts of different diet compositions, a new approach is required, which allows macronutrient impacts to be considered in the context of the whole diet.

Another consideration is that in an important respect, the composition of an experimental dietary treatment is not necessarily the same thing as the consumed diet, even in a nochoice paradigm. This is because an animal restricted to a nutritionally imbalanced food theoretically has the option to eat any one nutrient at the required level, albeit at the cost of over- and/or undereating other nutrients. Thus, a "low protein" experimental treatment might in reality not represent protein deficiency at all, but rather carbohydrate and/or fat surplus. Many experiments either do not measure intake, or else do not analyze the data to distinguish these possibilities.

\section{MOVING BEYOND THE WESTERN DIET; INTRODUCING NUTRITIONAL GEOMETRY}

\section{Background to Nutritional Geometry and Macronutrient Balance}

Nutritional Geometry (NG) is a multi-dimensional nutritional framework which assesses how macronutrient balance, rather than an individual macronutrient effect (e.g., high fat alone), impacts a given variable. Animal NG studies related to reproduction have employed a large number of diets which systematically vary across protein, carbohydrate and fat [e.g., $(54,55)$, Figure 1]. While this can make practical application logistically challenging, it offers a robust experimental design for studying the effects of macronutrient balance, which is more relevant to human obesity. Originally developed in studies of insects $(56,57)$, NG has since been used to study impacts of diet across a range of invertebrate taxa, particularly locusts, flies, crickets, and cockroaches. Given the adaptability of the framework, NG studies have extended to include many vertebrate species [e.g., fish (58), mice (55), companion animals (59), and non-human primates (60-62)]. Using principles which have been well established in these animal studies, Nutritional Geometry has also been directed increasingly toward human health $(63,64)$.

One insight to emerge from NG is the "protein leverage hypothesis", a theory to explain why modern diets are driving the obesity epidemic (34). The PLH posits that food intake in humans is driven most strongly to fulfil a target intake for protein, which passively influences ("leverages") the intake of non-protein energy $(34,65)$. A nutrient-specific appetite for protein is widespread among animal species, and evidence that this powerful protein appetite has interacted with a decline in the density of protein in the industrialized food supply to drive human obesity has accumulated rapidly in recent years [e.g., see (33)]. This is seen particularly in the modern diet of Western countries, where commonly consumed ultra-processed foods are low in protein relative to fats and carbohydrates, driving increased overall energy intake $(66,67)$. The impact of dietary manipulations on food intake is therefore an important consideration and should be measured in studies of nutritional effects on reproduction.

\section{Data Visualization Using Nutritional Geometry}

One of the major advantages of the NG approach is that it provides a graphical visualization of the effects of macronutrients. Data for each response variable are mapped on to a multidimensional nutrient space, allowing for a generalized overview of how an outcome is impacted by different diet compositions (Box 1). This method allows the individual and interactive effects of nutrients to be explored and disentangled. Results can be interpreted on the basis of the dietary macronutrient proportions (\% of total kcal from each nutrient) (68), or absolute macronutrient intakes ( $\mathrm{g}$ or kcal eaten of each nutrient). Absolute macronutrient intakes are a function of diet composition and the amounts of food an individual consumes. The NG approach provides a platform both for examining the effects of dietary nutrient mixtures on outcomes of interest, and for developing a guide for how experimental diets can be adjusted to achieve a desired outcome. For example, using this framework, it can be seen why diets high in protein are effective for weight loss-less calories are consumed (69). However, this excess protein consumption comes at a costanimals consuming these high protein/low carbohydrate diets show signs of metabolic disease and have shorter lifespans $(70-72)$.

\section{Nutritional Geometry in Action}

NG has been used to understand how diet affects different aspects of health, including trade-offs between lifespan and reproduction $(55,70,73)$. In general, these studies in mice and insects show that reproductive function is optimized by diets higher in protein content than diets that maximize lifespan. However, the strength of this response differs with sex $(55,70)$. This may be a true effect of differing nutrient requirements for reproduction in females versus males, or it may be an artefact of difficulties in assessing reproductive function in males (or likely a combination of both). Male reproduction in insects and fish is often assessed by an indirect measure of pre-mating investment in traits such as calling effort $(70,74)$, pheromone expression $(75,76)$, size of sexually-selected traits (77), and courting behavior (58). Other studies in both insects and mice have used measures of post- 
BOX 1 | A guide to interpreting Nutritional Geometry surface figures.

The figures presented in A and $\mathbf{B}$ represent two different experimental approaches to using Nutritional Geometry. In (A), the study design incorporates a range of different diet structures (protein/carbohydrate/fat \%), which vary in their energy density. Such a design will significantly impact overall energy intake and is therefore analyzed according to intake of each nutrient (typically in kJ/day). In (B), the study design incorporates different diet structures, but all diets have an equal energy density (isocaloric). This design typically only has minor effects on overall energy intake and is therefore analyzed according to the amount of each nutrient in the diet (typically as percentage of total kcal in the diet).

Both figures depict the impact of macronutrient balance on a given response variable (e.g., basal glucose). A color scale is used to indicate the level of the response variable (blue = minimum, red = maximum), with isolines giving numerical values. Isoline values vary by a fixed increment and the distance between isolines indicates the magnitude of nutrient effect over a given range (distant = minimal impact, close = substantial impact). In an intake-based model like (A), responses are often compared based on protein versus non-protein (carbohydrate and fat) energy. Alternatively, a $3 \times 3$ panel figure can be used to show primary interactions at the lower, median and upper quartile of the third macronutrient (e.g., protein versus carbohydrate, at the 25th, 50th and 75th percentile of fat). If appropriate to the medium, a rotating animation could be created to display all three dimensions simultaneously. In a diet-based model like (B), responses are compared based on diet structure, and the impacts of all three nutrients are analyzed simultaneously. Note that for the diagonal axis (in this case fat), the value increases from $0 \%$ at the diagonal axis to $100 \%$ at the origin.

A

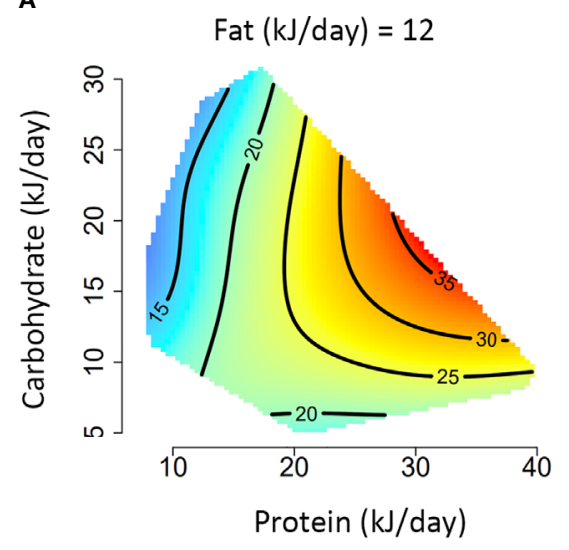

B

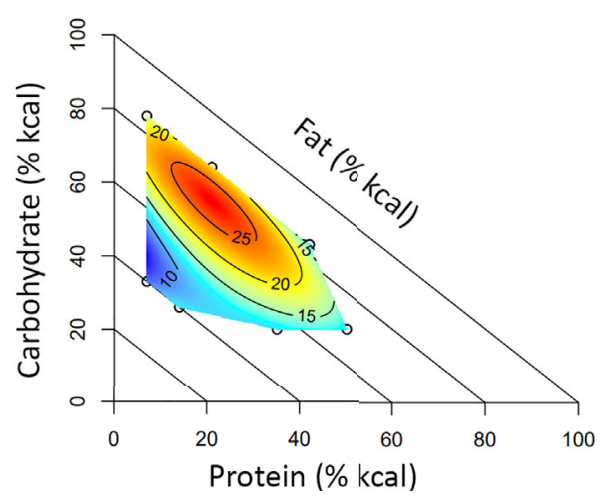

mating investment including testes and accessory glands size (55), sperm number and quality (78), and mating success (75). Nutrient effects on pre- and post-mating sexual traits can differ (79), and may be age- and context-dependent (80). Therefore, to accurately measure male reproductive function, multiple measures may need to be assessed (81).

A more complete assessment of male reproductive function may also be obtained by examining offspring produced from mating trials. Insect studies examining the proportion of eggs that hatched after standardized females were mated to experimental males have found that protein has negative (82, 83) or non-linear (78) effects on male fertility. Similarly, studies in Drosophila assessing mating in a competitive context have found that male reproductive success is maximized on diets with intermediate levels of protein $(84,85)$, and a low protein to carbohydrate ratio (86). These studies suggest that while female reproduction may be enhanced by increased dietary protein, male reproduction may be enhanced on lower protein to carbohydrate ratios-a diet similar to that which maximizes lifespan and metabolic health. However, as dietary nutrients have different effects on different aspects of male reproductive function (79), dietary recommendations may need to be specific to the desired outcome. As many of these studies have shown, rarely is one macronutrient wholly responsible for an effect; instead, the balance of macronutrients has often proven to be the most significant factor determining an outcome. Therein lies the advantage of the NG approach in shifting from studying a single nutrient to the interactions of multiple nutrients.

\section{IMPORTANT NUTRITIONAL CONSIDERATIONS TO IMPROVE AND EXPAND DIET STUDY DESIGNS}

\section{Caloric Density}

As discussed above, the varying caloric densities of control and western diets present an issue for the interpretation of results. When diets differ in their energy density, whether effects are derived from calories or macronutrients cannot be ascertaineda common point of contention in nutrition research (72). However, energy density can be standardized (made isocaloric) using indigestible fibre (e.g., cellulose), so that while protein, carbohydrate, and fat are at different levels, diets provide the same amount of energy per gram. Thus, isocaloric diets are a useful tool to improve the clarity of results and are commonly used in NG studies [e.g., (87)]. To study the effects of calories using the NG approach, researchers have the option of analyzing data on the basis of calories consumed (which differs only with the amount of food eaten, not the macronutrient balance). 
Alternatively, the study design can include a range of different macronutrient compositions at multiple calorie densities (e.g., low $3 \mathrm{kcal} / \mathrm{g}$ versus high $5 \mathrm{kcal} / \mathrm{g}$ for each combination of protein, carbohydrate, and fat).

\section{Macronutrient Quality}

Different foods differ in their biochemical profile of amino acids, fatty acids, and carbohydrate types $(88,89)$. As a result, the primary dietary sources of each macronutrient are likely to be just as important as overall macronutrient balance $(90,91)$, and a small number of studies support that this extends to reproduction. For example, when protein is supplied at a consistent level, vervet monkeys given animal protein (milk solids) had significantly poorer semen parameters than those fed plant protein (maize and legumes) (92). Similarly, dietary fat differentially impacts testicular enzyme activity depending on whether it is derived from virgin olive oil or butter (93). While virgin olive oil (monounsaturated fat) increased dipeptidyl peptidase IV activity, helping to maintain normal spermatogenesis, butter (saturated fat) increased the activity of gamma glutamyl transpeptidase, contributing to maintenance of the intracellular glutathione pool. While research into the effects of macronutrient source on reproduction is currently limited, it is likely to play an important role in response to diet and should also be a consideration in future studies.

\section{Micronutrients}

Beyond the macronutrients which provide dietary energy, Nutritional Geometry has also proven useful for studying the effects of dietary vitamins and minerals (79, 94). Many micronutrients, including calcium, sodium, zinc, potassium, and magnesium, have important roles in male reproduction, impacting testicular development, semen quality, and sperm biochemical processes (95). Micronutrient imbalances have also been suggested as a causal factor in unexplained female infertility (96). Reduced intake of dietary antioxidants including lycopene, vitamin C, folate, and carotenoids, has been associated with poorer semen parameters $(97,98)$. In addition, iodine intake outside the recommended range in men has been associated with increased time to conception (99), supporting a critical role for micronutrient balance in fertility. Supplementation of micronutrients, particularly those with antioxidant activity (e.g., vitamins $\mathrm{C}$ and $\mathrm{E}$, selenium), has been widely studied as a tool for improving reproductive outcomes of infertile men (100, 101). However, results have varied widely depending on the andrological diagnosis and the type, quantity and duration of micronutrient supplementation. While micronutrients clearly play important roles in male reproductive physiology, there have been no studies which systematically evaluate the impacts of dietary micronutrient intake on reproductive success. Micronutrients are particularly important to consider in the context of obesity, as micronutrient deficiency appears to be common in obese individuals $(102,103)$. Further, micronutrient supplementation may be able to limit negative effects of obesity on sperm function (104). Overall, there is an ongoing need for systematic research into how dietary micronutrients impact reproduction in both lean and obese males.

\section{Dietary Restriction}

In studies using both western diets and a NG approach, food is generally provided ad libitum. However, another approach used in dietary studies is to restrict either the amount or timing of access to food. There is good evidence that the temporal pattern of intake, including caloric restriction, periodic and intermittent fasting can have important effects in addition to those of diet composition (105). In relation to male reproduction, caloric restriction has been demonstrated to impact testicular gene expression $(106,107)$, including expression of leptin and ghrelin receptors (108). Intermittent fasting has also been shown to affect testicular gene expression (106), as well as testosterone production $(106,109,110)$. As caloric restriction and intermittent fasting remain popular (111) and recommended (112) weight loss strategies, future studies should also seek to investigate the effects of different intake patterns on reproductive health.

\section{Genetics and the Human Context}

One important consideration which spans both nutrition and reproductive biology, is the contribution of genetics. There are genetic factors, including copy number variants, gene mutations, single nucleotide polymorphisms and chromosomal abnormalities, implicated in obesity (113), and male infertility $(114,115)$. In the context of obesity, there is also the important consideration of nutrigenomics; the influence of nutrients themselves on gene expression (116). Given the important contribution of a unique genetic background to both response to diet and male fertility, this is a factor which poses a significant limitation in current studies. While C57BL/6 mice are used extensively as a model species in obesity research, this is an inbred sub-strain with limited genetic variability. Further, the consistent diet offered in animal studies does not reflect the depth of dietary variation in humans. While both constraints are inherent limitations of animal studies, they highlight the importance of moving from a single model to a variety of models (e.g., different mouse strains, non-human primates), and eventually to human studies. Making such a transition can allow for analyses based on populations with higher genetic variability. Further, Nutritional Geometry can be used to extend findings of animal studies into more complex human dietary patterns, analyzing either free-choice feeding from a selected range of foods (65) or dietary survey data (117).

\section{FEATURES OF STUDY DESIGN AND MEASUREMENT SPECIFIC TO MALE REPRODUCTION}

Investigations into how diet and obesity impact male reproductive function require the collaboration of two distinct research fields; nutrition and reproductive biology. In addition to considering the dietary aspect of animal studies, issues specific to studying male reproduction need to be considered. The first of these is the timing and length of diet treatments, which vary considerably in previous western diet-based studies (Table 1). In 
agricultural species, a significant body of research shows that many effects of diet (including over and under feeding) observed in pre-pubertal males are different in sexually mature males (118, 119). In terms of treatment length, many studies apply dietary interventions for a minimum of one complete spermatogenic cycle [34.5 days in mice (120), 56 days in rats (121)], to ensure that mature spermatozoa in the ejaculate are "exposed" to treatment throughout the entirety of spermatogenesis. Conversely, some recent studies have indicated impacts of diet on sperm function in the short term $(<2$ weeks) $(104,122)$. There is no wrong answer here in terms of when to start and stop treatment, but the interpretation of results should consider whether treatments were applied pre or post-puberty, and how treatment duration relates to sperm development.

Another important consideration is the measurement of reproductive function. Fertility in humans is simply defined as natural conception within 12 months of unprotected intercourse (123), with time to conception commonly used to describe an individual's likelihood of fertility (11). Previous diet studies have employed a range of assessments, including basic observational measurements [e.g., testis size (55), sperm motility, histology (7)], molecular biology assays [e.g., miRNAseq (12), proteomics (41), enzyme activity (8), oxidative stress markers (6)], and direct measures of conception success [i.e., fertilization rate, blastulation rate, pregnancy rate $(37,39)]$. While no one assay provides an infallible measurement of fertility, the combination of several variables will help to build a clearer picture of how diet and obesity impact male reproduction overall.

Finally, there should be a concerted effort to both capture and understand the unique impacts of diet on male compared to female reproductive physiology. It may be tempting to conclude that overall effects of diet on reproduction (i.e., increases or decreases in fertility) observed in one sex are equally applicable to the other sex. However, as discussed above, female and male reproductive performance appear to be optimized on different diets. Further, studies have indicated that female and male reproductive traits are differentially impacted by the same macronutrient ratios $(55,82,83,124)$. For example, male mice consuming a diet with an equal ratio of protein to carbohydrate had the largest testes and seminal vesicles, whereas female mice consuming the same diet had the largest uteri, but frequency of estrus, total follicle count and number of corpora lutea were reduced (55). Ultimately, future studies should endeavour to compare and contrast female and male reproductive responses to diet in order to determine whether the ideal macronutrient ratio to support reproduction is sex-specific.

\section{DISCUSSION}

As the prevalence of obesity continues to rise, and more negative implications for male reproductive physiology are discovered, its continued study remains a high priority. So far, research has provided strong evidence that a high fat diet negatively impacts male reproduction. However, as posited by the protein leverage hypothesis (34), dietary macronutrient balance rather than fat alone is likely to account for rising levels of obesity in the human population. In this context, the approach that is used to study obesity and the extent to which it captures the reality of the human experience must be considered. Using a tool such as Nutritional Geometry to study many different macronutrient combinations will not only provide information on which diets are detrimental but could also help guide research toward diets which may support reproductive function. This concept is particularly relevant when considering our approach to providing nutritional advice to men who are interested in conceiving.

Despite the observed impacts of obesity on male reproduction and the fact that men report $>80 \%$ of pregnancies are planned (125), widespread, professional pre-conception nutritional guidance for men remains almost non-existent $(126,127)$. The advice most commonly given and acted upon by men is to lose weight and eat a healthy diet (126). This is undoubtedly good advice, given the clear negative impacts of obesity on male reproduction $(18,20)$ and the strong relationship between diet and obesity risk $(34,128)$. However, there is no clear definition of what a "healthy diet" for reproduction is.

Switching to a "healthy diet" for most men means reducing intakes of foods containing saturated fat and added salt and sugars, and eating a wider variety of unprocessed foods (as recommended by nutritional dietary guidelines). While nutritional guidelines from different countries also give recommendations for macronutrient proportions (e.g., USA; $10 \%-35 \%$ protein, $45 \%-65 \%$ carbohydrate, $20 \%-35 \%$ fat as $\%$ of total kcal) (129), it remains unclear whether this diet structure is optimal for male fertility. While observational studies in humans have identified associations between dietary patterns and semen quality (130), the ideal macronutrient balance to support male reproduction is far from being well defined. Importantly, this is not necessarily the same as a diet which supports overall health and longevity, nor the same diet which supports female reproduction (55). In addition, it is not clear whether different advice is required in different contexts-taking other extrinsic, intrinsic, and genetic factors into account. There is a clear need to further explore how diet impacts male reproductive function in order to develop evidence-based preconception nutritional guidance for men.

There are many exciting potential applications of Nutritional Geometry in the landscape of male reproduction, covering both fundamental and applied aspects of reproductive research. Beginning with fundamental research conducted in rodent models, results would inform more targeted pre-clinical animal research, as well as nutritional intervention based clinical trials in humans. The information gathered by this approach would provide strong evidence on which to build preconception guidelines. On a fundamental level, NG can be used to explore which macronutrient ratio best supports male reproduction, and whether this differs from a) what supports female reproduction and b) what supports overall health. As the impacts of a paternal high fat diet on offspring health and reproduction are rapidly being uncovered (131), NG will likely be useful in exploring new avenues of paternal effects. NG may 
also be useful in exploring the effects of macronutrient source and weight loss strategies (e.g., caloric restriction, intermittent fasting) on reproductive function, and whether these factors alter the ideal macronutrient ratio. In the human context, it will be important to determine the impact of differing treatment durations to establish whether diet changes within the relatively short term pre-conception planning window ( $<12$ months) are a feasible strategy. With the rising use of assisted reproductive technologies (e.g., IVF) for conception (132), more clinically focused research could use NG to examine whether the ideal dietary macronutrient ratio to support reproduction is applicable outside of natural conception.

Animal studies have used high fat and western diets for decades in the pursuit of understanding the many consequences of obesity. While this approach has produced a wealth of information on the physiological impacts of obesity, it doesn't tell the whole story and limits what interpretations can be made about the role of diet. Nutritional Geometry shifts the focus from the effect of fat alone to complex and interacting effects of dietary macronutrient balance. Adopting the NG approach in future studies will provide more information on how the overall diet composition impacts male reproduction. In turn, this will allow for the development of evidence-based pre-conception nutritional guidelines for men, to support natural conception and potentially limit negative effects on offspring.

\section{REFERENCES}

1. Hales C, Carroll M, Fryar C, Ogden C. Prevalence of obesity among adults and youth: United States, 2015-2016. Natl Center Health Stat Data Brief (2017) 288:1-8.

2. Australian Institute of Health and Welfare. Overweight and obesity: An interactive insight. Canberra: AIHW (2019).

3. National Statistics. Health Survey for England 2017: Adult and Child Overweight and Obesity. England: NHS UK (2018).

4. Borges BC, Garcia-Galiano D, da Silveira Cruz-Machado S, Han X, Gavrilina GB, Saunders TL, et al. Obesity-induced infertility in male mice is associated with disruption of Crisp 4 expression and sperm fertilization capacity. Endocrinology (2017) 158:2930-43. doi: 10.1210/en.2017-00295

5. Pini T, Parks J, Russ J, Dzieciatkowska M, Hansen KC, Schoolcraft WB, et al. Obesity significantly alters the human sperm proteome, with potential implications for fertility. J Assisted Reprod Genet (2020) 37:777-87. doi: 10.1007/s10815-020-01707-8

6. Bakos HW, Mitchell M, Setchell BP, Lane M. The effect of paternal dietinduced obesity on sperm function and fertilization in a mouse model. Int $J$ Androl (2011) 34:402-10. doi: 10.1111/j.1365-2605.2010.01092.x

7. Fan Y, Liu Y, Xue K, Gu G, Fan W, Xu Y, et al. Diet-induced obesity in male C57BL/6 mice decreases fertility as a consequence of disrupted blood-testis barrier. PLoS One (2015) 10:e0120775. doi: 10.1371/journal.pone.0120775

8. Ferramosca A, Conte A, Moscatelli N, Zara V. A high-fat diet negatively affects rat sperm mitochondrial respiration. Andrology (2016) 4:520-5. doi: $10.1111 /$ andr.12182

9. Salas-Huetos A, Maghsoumi-Norouzabad L, James ER, Carrell DT, Aston KI, Jenkins TG, et al. Male adiposity, sperm parameters and reproductive hormones: An updated systematic review and collaborative meta-analysis. Obes Rev (2021) 22:e13082. doi: 10.1111/obr.13082

10. Ramlau-Hansen CH, Thulstrup AM, Nohr EA, Bonde JP, Sørensen TIA, Olsen J. Subfecundity in overweight and obese couples. Hum Reprod (2007) 22:1634-7. doi: 10.1093/humrep/dem035

11. Sallmén M, Sandler DP, Hoppin JA, Blair A, Baird DD. Reduced fertility among overweight and obese men. Epidemiology (2006) 17:520-3. doi: 10.1097/01.ede.0000229953.76862.e5

\section{AUTHOR CONTRIBUTIONS}

$\mathrm{TP}$ and $\mathrm{AC}$ conceived the review. TP, DR, SS, and AC wrote and reviewed the paper. All authors contributed to the article and approved the submitted version.

\section{FUNDING}

Authors are supported by research grants from Novo Nordisk (Foundation Grant NNF18OC0033754) and the NHMRC (Program Grant GNT1149976). Article Processing Charges were paid by the University of Sydney through an equity award to AC.

\section{ACKNOWLEDGMENTS}

We thank the editors for the invitation to contribute to this special issue, two reviewers whose insightful comments helped us strengthen our argument, and all the researchers (including those who we did not have the space to reference) whose work has contributed to the ideas put forward in this paper.

12. de Castro Barbosa T, Ingerslev LR, Alm PS, Versteyhe S, Massart J, Rasmussen M, et al. High-fat diet reprograms the epigenome of rat spermatozoa and transgenerationally affects metabolism of the offspring. Mol Metab (2016) 5:184-97. doi: 10.1016/j.molmet.2015.12.002

13. Fullston T, Ohlsson-Teague EMC, Print CG, Sandeman LY, Lane M. Sperm microRNA content is altered in a mouse model of male obesity, but the same suite of microRNAs are not altered in offspring's sperm. PLoS One (2016) 11: e0166076. doi: 10.1371/journal.pone.0166076

14. Reijo R, Lee T-Y, Salo P, Alagappan R, Brown LG, Rosenberg M, et al. Diverse spermatogenic defects in humans caused by $\mathrm{Y}$ chromosome deletions encompassing a novel RNA-binding protein gene. Nat Genet (1995) 10:383-93. doi: 10.1038/ng0895-383

15. Rochebrochard E, Thonneau P. Paternal age $\geq 40$ years: An important risk factor for infertility. Am J Obstet Gynecol (2003) 189:901-5. doi: 10.1067/ S0002-9378(03)00753-1

16. Lin CM, Chang WP, Doyle P, Wang JD, Lee LT, Lee CL, et al. Prolonged time to pregnancy in residents exposed to ionising radiation in cobalt-60contaminated buildings. Occup Environ Med (2010) 67:187-95. doi: 10.1136/ oem.2008.045260

17. Harlev A, Agarwal A, Gunes SO, Shetty A, du Plessis ,SS. Smoking and male infertility: An evidence-based review. World J Men's Health (2015) 33:14360. doi: 10.5534/wimh.2015.33.3.143

18. Chambers TJG, Richard RA. The impact of obesity on male fertility. Hormones (2015) 14:563-8. doi: 10.14310/horm.2002.1621

19. Craig JR, Jenkins TG, Carrell DT, Hotaling JM. Obesity, male infertility, and the sperm epigenome. Fertil Steril (2017) 107:848-59. doi: 10.1016/ j.fertnstert.2017.02.115

20. Raad G, Hazzouri M, Bottini S, Trabucchi M, Azoury J, Grandjean V. Paternal obesity: How bad is it for sperm quality and progeny health? Basic Clin Androl (2017) 27:20. doi: 10.1186/s12610-017-0064-9

21. Chavarro JE, Toth TL, Wright DL, Meeker JD, Hauser R. Body mass index in relation to semen quality, sperm DNA integrity, and serum reproductive hormone levels among men attending an infertility clinic. Fertil Steril (2010) 93:2222-31. doi: 10.1016/j.fertnstert.2009.01.100

22. Eisenberg ML, Kim S, Chen Z, Sundaram R, Schisterman EF, Buck Louis GM. The relationship between male BMI and waist circumference on semen 
quality: data from the LIFE study. Hum Reprod (2014) 29:193-200. doi: 10.1093/humrep/det 428

23. McPherson NO, Tremellen K. Increased BMI 'alone' does not negatively influence sperm function - a retrospective analysis of men attending fertility treatment with corresponding liver function results. Obes Res Clin Pract (2020) 14:164-7. doi: 10.1016/j.orcp.2020.03.003

24. Reis LO, Dias FGF. Male fertility, obesity, and bariatric surgery. Reprod Sci (2012) 19:778-85. doi: 10.1177/1933719112440053

25. Thomsen L, Humaidan P, Bungum L, Bungum M. The impact of male overweight on semen quality and outcome of assisted reproduction. Asian $J$ Androl (2014) 16:749-54. doi: 10.4103/1008-682X.125398

26. Hruby A, Manson JE, Qi L, Malik VS, Rimm EB, Sun Q, et al. Determinants and consequences of obesity. Am J Public Health (2016) 106:1656-62. doi: 10.2105/AJPH.2016.303326

27. Bray GA, Paeratakul S, Popkin BM. Dietary fat and obesity: A review of animal, clinical and epidemiological studies. Physiol Behav (2004) 83:54955. doi: 10.1016/j.physbeh.2004.08.039

28. Bray GA, Popkin BM. Dietary fat intake does affect obesity! Am J Clin Nutr (1998) 68:1157-73. doi: 10.1093/ajcn/68.6.1157

29. Field AE, Willett WC, Lissner L, Colditz GA. Dietary fat and weight gain among women in the Nurses' Health Study. Obesity (2007) 15:967-76. doi: 10.1038/oby.2007.616

30. Willett W. Dietary fat and obesity: An unconvincing relation. Am J Clin Nutr (1998) 68:1149-50. doi: 10.1093/ajcn/68.6.1149

31. Willett WC. Dietary fat and obesity: Lack of an important role. Scand J Nutr (2003) 47:58-67. doi: 10.1080/11026480310007953

32. Hall KD. The Potential Role of Protein Leverage in the US Obesity Epidemic. Obesity (2019) 27:1222-4. doi: 10.1002/oby.22520

33. Raubenheimer D, Simpson SJ. Protein leverage: Theoretical foundations and ten points of clarification. Obesity (2019) 27:1225-38. doi: 10.1002/ oby. 22531

34. Simpson SJ, Raubenheimer D. Obesity: The protein leverage hypothesis. Obes Rev (2005) 6:133-42. doi: 10.1111/j.1467-789X.2005.00178.x

35. Pellizzon MA, Ricci MR. Choice of laboratory rodent diet may confound data interpretation and reproducibility. Curr Dev Nutr (2020) 4:nzaa031. doi: $10.1093 / \mathrm{cdn} / \mathrm{nzaa} 031$

36. Duale N, Steffensen IL, Andersen J, Brevik A, Brunborg G, Lindeman B. Impaired sperm chromatin integrity in obese mice. Andrology (2014) 2:23443. doi: 10.1111/j.2047-2927.2013.00178.x

37. Ghanayem BI, Bai R, Kissling GE, Travlos G, Hoffler U. Diet-induced obesity in male mice is associated with reduced fertility and potentiation of acrylamide-induced reproductive toxicity. Biol Reprod (2009) 82:96-104. doi: 10.1095/biolreprod.109.078915

38. Fullston T, Ohlsson Teague EMC, Palmer NO, DeBlasio MJ, Mitchell M, Corbett $M$, et al. Paternal obesity initiates metabolic disturbances in two generations of mice with incomplete penetrance to the F2 generation and alters the transcriptional profile of testis and sperm microRNA content. FASEB J (2013) 27:4226-43. doi: 10.1096/fj.12-224048

39. McPherson NO, Bakos HW, Owens JA, Setchell BP, Lane M. Improving metabolic health in obese male mice via diet and exercise restores embryo development and fetal growth. PLoS One (2013) 8:e71459. doi: 10.1371/ journal.pone.0071459

40. Binder NK, Sheedy JR, Hannan NJ, Gardner DK. Male obesity is associated with changed spermatozoa Cox4il mRNA level and altered seminal vesicle fluid composition in a mouse model. Mol Hum Reprod (2015) 21:424-34. doi: 10.1093/molehr/gav010

41. Jarvis S, Gethings LA, Samanta L, Pedroni SMA, Withers DJ, Gray N, et al. High fat diet causes distinct aberrations in the testicular proteome. Int J Obes (2020) 44:1958-69. doi: 10.1038/s41366-020-0595-6

42. McPherson NO, Owens JA, Fullston T, Lane M. Preconception diet or exercise intervention in obese fathers normalizes sperm microRNA profile and metabolic syndrome in female offspring. Am J Physiol Endocrinol Metabol (2015) 308:E805-21. doi: 10.1152/ajpendo.00013.2015

43. Fullston T, Palmer NO, Owens JA, Mitchell M, Bakos HW, Lane M. Dietinduced paternal obesity in the absence of diabetes diminishes the reproductive health of two subsequent generations of mice. Hum Reprod (2012) 27:1391-400. doi: 10.1093/humrep/des030
44. Mitchell M, Bakos HW, Lane M. Paternal diet-induced obesity impairs embryo development and implantation in the mouse. Fertil Steril (2011) 95:1349-53. doi: 10.1016/j.fertnstert.2010.09.038

45. Palmer NO, Fullston T, Mitchell M, Setchell BP, Lane M. SIRT6 in mouse spermatogenesis is modulated by diet-induced obesity. Reprod Fertil Dev (2011) 23:929-39. doi: 10.1071/RD10326

46. Gromadzka-Ostrowska J. Effects of dietary fat on androgen secretion and metabolism. Reprod Biol (2006) 6:13-20.

47. Salameh E, Morel FB, Zeilani M, Déchelotte P, Marion-Letellier R. Animal models of undernutrition and enteropathy as tools for assessment of nutritional intervention. Nutrients (2019) 11:2233. doi: 10.3390/nu11092233

48. Ajuogu PK, Al-Aqbi MA, Hart RA, Wolden M, Smart NA, McFarlane JR. The effect of dietary protein intake on factors associated with male infertility: A systematic literature review and meta-analysis of animal clinical trials in rats. Nutr Health (2020) 26:53-64. doi: 10.1177/0260106019900731

49. Morgan HL, Ampong I, Eid N, Rouillon C, Griffiths HR, Watkins AJ. Low protein diet and methyl-donor supplements modify testicular physiology in mice. Reproduction (2020) 159:627-41. doi: 10.1530/REP-19-0435

50. Watkins AJ, Dias I, Tsuro H, Allen D, Emes RD, Moreton J, et al. Paternal diet programs offspring health through sperm- and seminal plasma-specific pathways in mice. Proc Natl Acad Sci U S A (2018) 115:10064. doi: 10.1073/ pnas. 1806333115

51. Watkins AJ, Sirovica S, Stokes B, Isaacs M, Addison O, Martin RA. Paternal low protein diet programs preimplantation embryo gene expression, fetal growth and skeletal development in mice. Biochim Biophys Acta (2017) 1863:1371-81. doi: 10.1016/j.bbadis.2017.02.009

52. Morgan HL, Aljumah A, Rouillon C, Watkins AJ. Paternal low protein diet and the supplementation of methyl-donors impact fetal growth and placental development in mice. Placenta (2021) 103:124-33. doi: 10.1016/ j.placenta.2020.10.020

53. Morgan HL, Paganopoulou P, Akhtar S, Urquhart N, Philomin R, Dickinson $\mathrm{Y}$, et al. Paternal diet impairs F1 and F2 offspring vascular function through sperm and seminal plasma specific mechanisms in mice. J Physiol (2020) 598:699-715. doi: 10.1113/JP278270

54. Paris V, Solon-Biet S, Senior A, Edwards M, Desai R, Tedla N, et al. Defining the impact of dietary macronutrient balance on PCOS traits. Nat Commun (2020) 11:5262. doi: 10.1038/s41467-020-19003-5

55. Solon-Biet SM, Walters KA, Simanainen UK, McMahon AC, Ruohonen K, Ballard JWO, et al. Macronutrient balance, reproductive function, and lifespan in aging mice. Proc Natl Acad Sci U S A (2015) 112:3481-6. doi: 10.1073/pnas.1422041112

56. Raubenheimer D, Simpson SJ. The geometry of compensatory feeding in the locust. Anim Behav (1993) 45:953-64. doi: 10.1006/anbe.1993.1114

57. Simpson SJ, Raubenheimer D. A multi-level analysis of feeding behaviour: The geometry of nutritional decisions. Philos Trans R Soc Lond Ser B: Biol Sci (1993) 342:381-402. doi: 10.1098/rstb.1993.0166

58. Moatt J, Fyfe M, Heap E, Mitchell L, Moon F, Walling C. Reconciling nutritional geometry with classical dietary restriction: Effects of nutrient intake, not calories, on survival and reproduction. Aging Cell (2019) 18: e12868. doi: 10.1111/acel.12868

59. Hewson-Hughes AK, Hewson-Hughes VL, Colyer A, Miller AT, McGrane SJ, Hall SR, et al. Geometric analysis of macronutrient selection in breeds of the domestic dog, Canis lupus familiaris. Behav Ecol (2013) 24:293-304. doi: 10.1093/beheco/ars168

60. Cui Z-W, Wang Z-L, Shao Q, Raubenheimer D, Lu J-Q. Macronutrient signature of dietary generalism in an ecologically diverse primate in the wild. Behav Ecol (2018) 29:804-13. doi: 10.1093/beheco/ary003

61. Guo S-T, Hou R, Garber PA, Raubenheimer D, Righini N, Ji W-H, et al. Nutrient-specific compensation for seasonal cold stress in a free-ranging temperate colobine monkey. Funct Ecol (2018) 32:2170-80. doi: 10.1111/ 1365-2435.13134

62. Rothman JM, Raubenheimer D, Chapman CA. Nutritional geometry: gorillas prioritize non-protein energy while consuming surplus protein. Biol Lett (2011) 7:847-9. doi: 10.1098/rsbl.2011.0321

63. Raubenheimer D, Simpson SJ. Nutritional Ecology and Human Health. Annu Rev Nutr (2016) 36:603-26. doi: 10.1146/annurev-nutr-071715051118 
64. Simpson SJ, Le Couteur DG, James DE, George J, Gunton JE, Solon-Biet SM, et al. The Geometric Framework for Nutrition as a tool in precision medicine. Nutr Healthy Aging (2017) 4:217-26. doi: 10.3233/NHA-170027

65. Simpson SJ, Batley R, Raubenheimer D. Geometric analysis of macronutrient intake in humans: The power of protein? Appetite (2003) 41:123-40. doi: 10.1016/S0195-6663(03)00049-7

66. Hall KD, Ayuketah A, Brychta R, Cai H, Cassimatis T, Chen KY, et al. Ultraprocessed diets cause excess calorie intake and weight gain: An inpatient randomized controlled trial of ad libitum food intake. Cell Metab (2019) 30:67-77.e3. doi: 10.1016/j.cmet.2019.05.008

67. Martínez Steele E, Raubenheimer D, Simpson SJ, Baraldi LG, Monteiro CA. Ultra-processed foods, protein leverage and energy intake in the USA. Public Health Nutr (2018) 21:114-24. doi: 10.1017/S1368980017001574

68. Raubenheimer D. Toward a quantitative nutritional ecology: The rightangled mixture triangle. Ecol Monogr (2011) 81:407-27. doi: 10.1890/101707.1

69. Freedman MR, King J, Kennedy E. Popular diets: A scientific review. Obes Res (2001) 9:1s-40s. doi: 10.1038/oby.2001.113

70. Maklakov AA, Simpson SJ, Zajitschek F, Hall MD, Dessmann J, Clissold F, et al. Sex-specific fitness effects of nutrient intake on reproduction and lifespan. Curr Biol (2008) 18:1062-6. doi: 10.1016/j.cub.2008.06.059

71. Mittendorfer B, Klein S, Fontana L. A word of caution against excessive protein intake. Nat Rev Endocrinol (2020) 16:59-66. doi: 10.1038/s41574019-0274-7

72. Simpson SJ, Le Couteur DG, Raubenheimer D, Solon-Biet SM, Cooney GJ, Cogger VC, et al. Dietary protein, aging and nutritional geometry. Ageing Res Rev (2017) 39:78-86. doi: 10.1016/j.arr.2017.03.001

73. Lee KP, Simpson SJ, Clissold FJ, Brooks R, Ballard JWO, Taylor PW, et al. Lifespan and reproduction in Drosophila: New insights from nutritional geometry. Proc Natl Acad Sci U S A (2008) 105:2498. doi: 10.1073/ pnas.0710787105

74. Rapkin J, Archer CR, Grant CE, Jensen K, House CM, Wilson AJ, et al. Little evidence for intralocus sexual conflict over the optimal intake of nutrients for life span and reproduction in the black field cricket Teleogryllus commodus. Evolution (2017) 71:2159-77. doi: 10.1111/evo.13299

75. Rapkin J, Jensen K, House CM, Sakaluk SK, Sakaluk JK, Hunt J. The complex interplay between macronutrient intake, cuticular hydrocarbon expression and mating success in male decorated crickets. J Evol Biol (2017) 30:711-27. doi: $10.1111 /$ jeb.13036

76. South SH, House CM, Moore AJ, Simpson SJ, Hunt J. Male cockroaches prefer a high carbohydrate diet that makes them more attractive to females: Implications for the study of condition dependence. Evolution (2011) 65:1594-606. doi: 10.1111/j.1558-5646.2011.01233.x

77. Sentinella AT, Crean AJ, Bonduriansky R. Dietary protein mediates a tradeoff between larval survival and the development of male secondary sexual traits. Funct Ecol (2013) 27:1134-44. doi: 10.1111/1365-2435.12104

78. Bunning H, Rapkin J, Belcher L, Archer CR, Jensen K, Hunt J. Protein and carbohydrate intake influence sperm number and fertility in male cockroaches, but not sperm viability. Proc R Soc Lond Ser B: Biol Sci (2015) 282:20142144. doi: 10.1098/rspb.2014.2144

79. Ng SH, Simpson SJ, Simmons LW. Macronutrients and micronutrients drive trade-offs between male pre- and postmating sexual traits. Funct Ecol (2018) 32:2380-94. doi: 10.1111/1365-2435.13190

80. Macartney EL, Crean AJ, Bonduriansky R. Adult dietary protein has ageand context-dependent effects on male post-copulatory performance. J Evol Biol (2017) 30:1633-43. doi: 10.1111/jeb.13087

81. Moatt JP, Nakagawa S, Lagisz M, Walling CA. The effect of dietary restriction on reproduction: a meta-analytic perspective. BMC Evol Biol (2016) 16:199. doi: 10.1186/s12862-016-0768-z

82. Bonduriansky R, Runagall-McNaull A, Crean AJ. The nutritional geometry of parental effects: Maternal and paternal macronutrient consumption and offspring phenotype in a neriid fly. Funct Ecol (2016) 30:1675-86. doi: $10.1111 / 1365-2435.12643$

83. Zajitschek F, Zajitschek SRK, Friberg U, Maklakov AA. Interactive effects of sex, social environment, dietary restriction, and methionine on survival and reproduction in fruit flies. AGE (2013) 35:1193-204. doi: 10.1007/s11357012-9445-3
84. Fricke C, Bretman A, Chapman T. Adult male nutrition and reproductive success in Drosophila melanogaster. Evolution (2008) 62:3170-7. doi: 10.1111/j.1558-5646.2008.00515.x

85. Reddiex AJ, Gosden TP, Bonduriansky R, Chenoweth SF. Sex-specific fitness consequences of nutrient intake and the evolvability of diet preferences. Am Nat (2013) 182:91-102. doi: 10.1086/670649

86. Jensen K, McClure C, Priest NK, Hunt J. Sex-specific effects of protein and carbohydrate intake on reproduction but not lifespan in Drosophila melanogaster. Aging Cell (2015) 14:605-15. doi: 10.1111/acel.12333

87. Solon-Biet S, McMahon A, Ballard J, Ruohonen K, Wu L, Cogger V, et al. The Ratio of Macronutrients, Not Caloric Intake, Dictates Cardiometabolic Health, Aging, and Longevity in Ad Libitum-Fed Mice. Cell Metab (2014) 19:418-30. doi: 10.1016/j.cmet.2014.02.009

88. Hoffman JR, Falvo MJ. Protein - Which is best? J Sports Sci Med (2004) 3:118-30.

89. Orsavova J, Misurcova L, Ambrozova JV, Vicha R, Mlcek J. Fatty acids composition of vegetable oils and its contribution to dietary energy intake and dependence of cardiovascular mortality on dietary intake of fatty acids. Int J Mol Sci (2015) 16:12871-90. doi: 10.3390/ijms160612871

90. Solon-Biet SM, Cogger VC, Pulpitel T, Wahl D, Clark X, Bagley E, et al. Branched chain amino acids impact health and lifespan indirectly via amino acid balance and appetite control. Nat Metab (2019) 1:532-45. doi: 10.1038/ s42255-019-0059-2

91. Wali JA, Raubenheimer D, Senior AM, Le Couteur DG, Simpson SJ. Cardiometabolic consequences of dietary carbohydrates: reconciling contradictions using nutritional geometry. Cardiovasc Res (2021) 117:386-401. doi: $10.1093 / \mathrm{cvr} / \mathrm{cvaa} 136$

92. Johnson Q, Veith W. Effect of dietary plant and animal protein intake on sperm quality in monkeys. Arch Androl (2001) 46:145-51. doi: 10.1080/ 01485010151094092

93. Domínguez-Vías G, Segarra A, Martínez-Cañamero M, Ramírez-Sanchez M, Prieto I. Influence of a virgin olive oil versus butter plus cholesterol-enriched diet on testicular enzymatic activities in adult male rats. Int J Mol Sci (2017) 18:1701. doi: 10.3390/ijms18081701

94. Harrison SJ, Raubenheimer D, Simpson SJ, Godin JG, Bertram SM. Towards a synthesis of frameworks in nutritional ecology: Interacting effects of protein, carbohydrate and phosphorus on field cricket fitness. Proc Biol Sci (2014) 281:20140539. doi: 10.1098/rspb.2014.0539

95. Skoracka K, Eder P, Łykowska-Szuber L, Dobrowolska A, KrelaKaźmierczak I. Diet and nutritional factors in male (in)fertilityunderestimated factors. J Clin Med (2020) 9:1400. doi: 10.3390/jcm9051400

96. Noventa M, Quaranta M, Vitagliano A, Cinthya V, Valentini R, Campagnaro $\mathrm{T}$, et al. May underdiagnosed nutrition imbalances be responsible for a portion of so-called unexplained infertility?From diagnosis to potential treatment options. Reprod Sci (2016) 23:812-22. doi: $10.1177 / 1933719115620496$

97. Mendiola J, Torres-Cantero AM, Vioque J, Moreno-Grau JM, Ten J, Roca M, et al. A low intake of antioxidant nutrients is associated with poor semen quality in patients attending fertility clinics. Fertil Steril (2010) 93:1128-33. doi: 10.1016/j.fertnstert.2008.10.075

98. Zareba P, Colaci DS, Afeiche M, Gaskins AJ, Jørgensen N, Mendiola J, et al. Semen quality in relation to antioxidant intake in a healthy male population. Fertil Steril (2013) 100:1572-9. doi: 10.1016/j.fertnstert.2013.08.032

99. Sun Y, Chen C, Liu GG, Wang M, Shi C, Yu G, et al. The association between iodine intake and semen quality among fertile men in China. BMC Public Health (2020) 20:461. doi: 10.1186/s12889-020-08547-2

100. Buhling JK, Laakmann JE. The effect of micronutrient supplements on male fertility. Curr Opin Obstet Gynecol (2014) 26:199-209. doi: 10.1097/ GCO.0000000000000063

101. Buhling K, Schumacher A, Eulenburg CZ, Laakmann E. Influence of oral vitamin and mineral supplementation on male infertility: A meta-analysis and systematic review. Reprod Biomed Online (2019) 39:269-79. doi: 10.1016/j.rbmo.2019.03.099

102. Krzizek E-C, Brix J, Herz C, Kopp H, Schernthaner G-H, Schernthaner G, et al. Prevalence of micronutrient deficiency in patients with morbid obesity before bariatric surgery. Obes Surg (2018) 28:643-8. doi: 10.1007/s11695017-2902-4 
103. McKay J, Ho S, Jane M, Pal S. Overweight \& obese Australian adults and micronutrient deficiency. BMC Nutr (2020) 6:12-2. doi: 10.1186/s40795020-00336-9

104. McPherson N, Shehadeh H, Fullston T, Zander-Fox D, Lane M. Dietary micronutrient supplementation for 12 days in obese male mice restores sperm oxidative stress. Nutrients (2019) 11:2196. doi: 10.3390/nu11092196

105. Di Francesco A, Di Germanio C, Bernier M, de Cabo R. A time to fast. Science (2018) 362:770-5. doi: 10.1126/science.aau2095

106. Martin B, Pearson M, Brenneman R, Golden E, Wood W, Prabhu V, et al. Gonadal transcriptome alterations in response to dietary energy intake: Sensing the reproductive environment. PLoS One (2009) 4:e4146. doi: 10.1371/journal.pone.0004146

107. Sharov AA, Falco G, Piao Y, Poosala S, Becker KG, Zonderman AB, et al. Effects of aging and calorie restriction on the global gene expression profiles of mouse testis and ovary. BMC Biol (2008) 6:24. doi: 10.1186/1741-7007-624

108. Martins AD, Jarak I, Morais T, Carvalho RA, Oliveira PF, Monteiro MP, et al. Caloric restriction alters the hormonal profile and testicular metabolome, resulting in alterations of sperm head morphology. Am J Physiol Endocrinol Metabol (2020) 318:E33-43. doi: 10.1152/ ajpendo.00355.2019

109. Kumar S, Kaur G. Intermittent fasting dietary restriction regimen negatively influences reproduction in young rats: A study of hypothalamo-hypophysial-gonadal axis. PLoS One (2013) 8:e52416. doi: 10.1371/journal.pone.0052416

110. Lynn SE, Stamplis TB, Barrington WT, Weida N, Hudak CA. Food, stress, and reproduction: Short-term fasting alters endocrine physiology and reproductive behavior in the zebra finch. Horm Behav (2010) 58:214-22. doi: 10.1016/j.yhbeh.2010.03.015

111. Obert J, Pearlman M, Obert L, Chapin S. Popular weight loss strategies: A review of four weight loss techniques. Curr Gastroenterol Rep (2017) 19:61. doi: 10.1007/s11894-017-0603-8

112. National Library of Medicine. Expert panel report: Guidelines (2013) for the management of overweight and obesity in adults. Obesity (2014) 22:S41S410. doi: 10.1002/oby.20660

113. Thaker VV. Genetic and epigenetic causes of obesity. Adolesc Med State Art Rev (2017) 28:379-405.

114. Krausz C, Riera-Escamilla A. Genetics of male infertility. Nat Rev Urol (2018) 15:369-84. doi: 10.1038/s41585-018-0003-3

115. Xavier MJ, Salas-Huetos A, Oud MS, Aston KI, Veltman JA. Disease gene discovery in male infertility: Past, present and future. Hum Genet (2021) 140:7-19. doi: 10.1007/s00439-020-02202-x

116. Peña-Romero AC, Navas-Carrillo D, Marín F, Orenes-Piñero E. The future of nutrition: Nutrigenomics and nutrigenetics in obesity and cardiovascular diseases. Crit Rev Food Sci Nutr (2017) 58:3030-41. doi: 10.1080/ 10408398.2017.1349731

117. Martinez-Cordero C, Kuzawa CW, Sloboda DM, Stewart J, Simpson SJ, Raubenheimer D. Testing the Protein Leverage Hypothesis in a free-living human population. Appetite (2012) 59:312-5. doi: 10.1016/ j.appet.2012.05.013

118. Kenny DA, Byrne CJ. Review: The effect of nutrition on timing of pubertal onset and subsequent fertility in the bull. Animal (2018) 12:s36-44. doi: $10.1017 /$ S1751731118000514

119. Martin GB, Blache D, Miller DW, Vercoe PE. Interactions between nutrition and reproduction in the management of the mature male ruminant. Animal (2010) 4:1214-26. doi: 10.1017/S1751731109991674
120. Oakberg EF. Duration of spermatogenesis in the mouse and timing of stages of the cycle of the seminiferous epithelium. Am J Anat (1956) 99:507-16. doi: 10.1002/aja.1000990307

121. Creasy DM. Evaluation of testicular toxicity in safety evaluation studies: the appropriate use of spermatogenic staging. Toxicol Pathol (1997) 25:119-31. doi: $10.1177 / 019262339702500201$

122. Nätt D, Kugelberg U, Casas E, Nedstrand E, Zalavary S, Henriksson P, et al. Human sperm displays rapid responses to diet. PLoS Biol (2019) 17: e3000559. doi: 10.1371/journal.pbio.3000559

123. Zegers-Hochschild F, Adamson GD, de Mouzon J, Ishihara O, Mansour R, Nygren K, et al. International committee for monitoring assisted reproductive technology (ICMART) and the world health organization (WHO) revised glossary of ART terminology, 2009. Fertil Steril (2009) 92:1520-4. doi: 10.1016/j.fertnstert.2009.09.009

124. Adler MI, Cassidy EJ, Fricke C, Bonduriansky R. The lifespan-reproduction trade-off under dietary restriction is sex-specific and context-dependent. Exp Gerontol (2013) 48:539-48. doi: 10.1016/j.exger.2013.03.007

125. Bodin M, Käll L, Tydén T, Stern J, Drevin J, Larsson M. Exploring men’s pregnancyplanning behaviour and fertility knowledge: A survey among fathers in Sweden. Upsala J Med Sci (2017) 122:127-35. doi: 10.1080/03009734.2017.1316531

126. Shawe J, Patel D, Joy M, Howden B, Barrett G, Stephenson J. Preparation for fatherhood: A survey of men's preconception health knowledge and behaviour in England. PLoS One (2019) 14:e0213897. doi: 10.1371/ journal.pone.0213897

127. Frey KA, Navarro SM, Kotelchuck M, Lu MC. The clinical content of preconception care: Preconception care for men. Am J Obstet Gynecol (2008) 199:S389-95. doi: 10.1016/j.ajog.2008.10.024

128. Jessri M, Wolfinger RD, Lou WY, L'Abbé MR. Identification of dietary patterns associated with obesity in a nationally representative survey of Canadian adults: Application of a priori, hybrid, and simplified dietary pattern techniques. Am J Clin Nutr (2017) 105:669-84. doi: 10.3945/ ajcn.116.134684

129. Institute of Medicine. Dietary reference intakes for energy, carbohydrate, fiber, fat, fatty acids, cholesterol, protein, and amino acids Vol. pp. Washington, DC: The National Academies Press (2005). p. 1358.

130. Salas-Huetos A, Bulló M, Salas-Salvadó J. Dietary patterns, foods and nutrients in male fertility parameters and fecundability: A systematic review of observational studies. Hum Reprod Update (2017) 23:371-89. doi: 10.1093/humupd/dmx006

131. Schagdarsurengin U, Steger K. Epigenetics in male reproduction: Effect of paternal diet on sperm quality and offspring health. Nat Rev Urol (2016) 13:584-95. doi: 10.1038/nrurol.2016.157

132. Ferraretti AP, Nygren K, Andersen AN, de Mouzon J, Kupka M, Calhaz-Jorge C, et al. Trends over 15 years in ART in Europe: An analysis of 6 million cycles. Hum Reprod Open (2017) 2017:hox012. doi: 10.1093/hropen/hox012

Conflict of Interest: The authors declare that the research was conducted in the absence of any commercial or financial relationships that could be construed as a potential conflict of interest.

Copyright (c) 2021 Pini, Raubenheimer, Simpson and Crean. This is an open-access article distributed under the terms of the Creative Commons Attribution License (CC BY). The use, distribution or reproduction in other forums is permitted, provided the original author(s) and the copyright owner(s) are credited and that the original publication in this journal is cited, in accordance with accepted academic practice. No use, distribution or reproduction is permitted which does not comply with these terms. 